\title{
TOURISM AND MUSICAL PERFORMING ARTS IN CHINA IN THE FIRST DECADE OF THE TWENTY- FIRST CENTURY: A PERSONAL VIEW
}

\author{
COLIN MACKERRAS \\ Griffith University, Australia
}

This paper aims to be a personal and limited view of how tourism has affected the musical performing arts in China in the first decade of the twenty-first century. As a personal interpretation, it is based largely on experience, but supplemented by websites, statements and some Chinese and English-language scholarly studies. The musical performing arts focused on include various styles of indigenous musical theater ( $x i q u$ 戯 曲), especially Kunqu 芘曲 and Jingju 京劇, and a variety of minority performance traditions.

Chinese tourism has itself increased enormously in recent years. Not only are more people visiting China, but more Chinese are travelling within their own country and abroad. ${ }^{1}$ Increasing numbers of sites and objects have been opened to tourists and even deliberately exposed to "the tourist gaze" (Urry 2002) in order to make them more widely known and to make money. Among these tourist sites and objects are many that are cultural in one way or another, such as historical and/or religious buildings, ethnic villages, and live performances. Especially relevant for this paper is the fact that Chinese tourist companies have specifically

\footnotetext{
${ }^{1}$ According to official figures (cited by Ryan and $\mathrm{Gu}$ 2009: 6), inbound tourist numbers rose from 17,833,100 in 1984 to 132 million in 2007, while over the same years domestic tourist numbers increased from 240 million to 1.61 billion. Inbound tourists in both years include those from Hong Kong, Macau and Taiwan. The figures for both inbound and domestic tourists have risen consistently year after year, apart from a slight downturn in 2003 because of the SARS crisis. Over the same years, the total receipts from inbound tourists multiplied by nearly 35 times, while income from domestic tourists expanded nearly 100 times (Ryan and Gu 2009: 6).
}

CHINOPERL Papers No. 30 (2011)

(C)2011 by the Conference on Chinese Oral and Performing Literature 
CHINOPERL Papers No. 30

included various forms of xiqu in the list of cultural elements with the potential to attract foreign tourist dollars. The "Chinese Opera" section of the website of one professional tourist agency, which is clearly interested in getting foreigners to sign up to tour China with them, begins with the claim "Chinese Opera is China's national essence." The opening of this section also claims Chinese opera as the first of the Chinese performing arts to enter the international arena, and quotes "One American" as having said: "If China does not have Chinese opera, I will not recognize China any more" (Visit Our China n.d.). Referring more specifically to Jingju, one Chinese reporter describes it as "the national essence" (guocui 國粹) and “a cultural ambassador" (wenhua dashi 文化大使) (Xue 2003: 40), and thus an appropriate tourist attraction. ${ }^{2}$

Tourism studies has become a formally recognized and expanding area of research in recent years. In the case of Chinese tourism, several books and numerous articles have been published recently in English and Chinese. These tend to be broad-ranging with a focus on the relationship between tourism and economic development. ${ }^{3}$ Topics such as tourism and ethnic minorities, ${ }^{4}$ especially the Tibetans, ${ }^{5}$ and tourism and the environment, have attracted a good deal of attention. The scholarly literature also addresses interactions between culture and tourism. One monograph, for instance, deals with tourism and cultural authority in the context of scenic spots (Nyíri 2006). In China, there is an Institute of History, Culture, and Tourism (Lishi wenhua yи lüyou xиeyuan 歴史文化 與旅游學院) at the Southern Jiangxi Normal College (Gannan shifan xueyuan 赣南師范學院), which suggests some attention to the connection between culture and tourism. The performing arts and tourism has not been a major topic for western scholars working on tourism and culture, but in the Chinese language at least two Master's theses have been written on it (Li 2007 and Bi 2007). There are also studies of the place of "tourist Jingju" in contemporary Jingju (e.g., Xu 1999). However, the extent of research in English or Chinese does not match the importance of this subject.

\footnotetext{
${ }^{2}$ See also Zhengyi ci n.d., where the term guocui is used with reference to Jingju in an especially prominent fashion.

${ }^{3}$ Examples are Xu 1999; Lew, Yu, Ap, and Zhang 2003; and Wen and Tisdell 2001.

${ }^{4}$ For example, see Oakes 1998, Su and Teo 2009, and Bai 2007.

${ }^{5}$ Examples include Kolås 2008 and Cingcade 1998.
} 
MACKERRAS, Tourism and Musical Performing Arts

As will be explained in the section on theory below, tourism studies includes some highly contested issues. In particular, the relationship between tourism and cultural survival is a very controversial one. Debates of this kind justify research and analysis on the topic. The relative lack of scholarly literature on the interrelationship between tourism and Chinese performing arts, mentioned in the preceding paragraph, merely adds justification to turning attention on this topic.

\section{Theory}

A tourist is understood as any person visiting a place away from home for the principal purpose of holiday or recreation, even if their aim is also educational. Tourists can be divided into two basic types. One comprises older and richer travellers who go in pre-paid and pre-organized groups. The other is younger and less rich "backpackers" who may wander around with comparatively little organization or planning and pride themselves on travelling cheaply.

There are several different kinds of tourism. They include ecotourism, ethnic tourism, adventure tourism, and heritage tourism. The one most appropriate to this paper is heritage tourism, which focuses on nostalgia for the past and may include art works, historic buildings, and even scenery in its purview. This kind of tourism is extremely popular in China, where those formulating tourism policy now feel that China has a traditional culture worth showing to the world and to its own people. This is a great change from the 1950s and 1960s, when for those in charge of what tourism there was, showcasing China's revolution and the economic and social benefits it had brought about was paramount. According to Marjorie Kibby (2000: 140), heritage tourism represents "a way of recuperating the past for contemporary tourists, and is part of a wider nostalgia for traditional social values, and an appreciation of the way things were, or at least are perceived to have been."

There is already a significant literature on the relationship between tourism and culture in general. On the whole, this literature tends to be negative about the impact of tourism on culture, arguing that tourism has a way of turning culture into a mere commodity for sale and purchase, not a part of human existence. David Weaver and Martin Opperman (2000: 286) call the commodification of culture in response to the tourist market "a major negative sociocultural impact associated with tourism." One of the harshest critics is Davydd Greenwood, who regards tourism as a violation of cultural rights. In his view (Greenwood 1989:179), "Culture is being 
packed, priced, and sold like building lots, rights-of-way, fast food, and room service, as the tourism industry inexorably extends its grasp."

Huib Schippers, whose focus is music education, not tourism, cites an example in which tourism might actually help to revive a dying art form, in this case a "beautiful sung poetry with instrumental accompaniment known as ca trù," which once flourished in Vietnamese villages but when introduced into the cities became the site of special houses that could function also as brothels. This association with prostitution drove the Communist government to outlaw the song form after it came to power in 1954; this forced the musicians back to the villages, where they lost their prestige, their training system, and their audiences. But the early twentyfirst century has seen an attempt to revive the art. A number of advocates have submitted a proposal to UNESCO to acknowledge this art as a masterpiece of Intangible Cultural Heritage. Scholars are documenting its history and characteristics and resuming performances. Advocates aspire to re-establish ca trù houses open to Vietnamese audiences and the cultural tourist trade, "which could charge tourists U.S. \$25 for an evening of authentic entertainment (rather than the toned-down tourist music in most hotels)." This provides funds for the musicians and training a new generation of artists (Schippers 2010: 135). Government authorities have remained sceptical about this form of art. Although they have done nothing to obstruct its revival, they have not contributed to the process either.

I agree with the drawing of a distinction between "authentic entertainment" and "toned down tourist music." However, this distinction raises the complex and difficult question of precisely what constitutes "authenticity" and who decides what is authentic and what is not. As a contested notion, authenticity has spawned its own literature. ${ }^{6}$ However, one useful, clear, and simple definition has it that "the present-day authenticity pays homage to the 'original' concept" (Chhabra, Healy, and Sills 2003: 705). Yong-guang Zhou and Emily Ma see authenticity as resting upon "the authorization by the host community of those aspects of their culture, traditions and way of life that are presented to tourists for their consumption" (Zhou and Ma 2009: 295). In other words, it is the people presenting their culture to the tourist who should decide what is authentic and what is not.

\footnotetext{
${ }^{6}$ For example, Chhabra, Healy, and Sills 2003.
} 
The last quotation brings us to the specific case of tourism in China. ${ }^{7}$ Timothy Oakes is the author of a study of tourism in a village in Guizhou Province. This book, which has become one of the main Europeanlanguage works on ethnic tourism in China, approaches the topic in terms of modernization. Oakes stayed in a village that was one of several dozen in the province promoted to develop ethnic tourism. He states (Oakes 1998: 10) that: "As an officially recognized tourist village, it was essentially part of a large state-sponsored modernization and development project." Modernity can be subdivided into "authentic" and "false" types, and Oakes (1998: 229) makes it clear that he puts ethnic tourism into the category of "false modernity." He also takes up the issue of culture and cultural politics. Rather than seeing tourism as something that can both destroy and preserve culture at the same time, he prefers to see it as "itself part of the inherently contradictory process of cultural change associated with modernity" (Oakes 1998: 70).

In their study of "the production and consumption of heritage" among the Naxi 納西 people in Lijiang, Yunnan Province, Su Xiaobo and Peggy Teo propose an analytical framework in which those involved in tourism, such as international companies (the global), the Chinese state (the national) and the Naxi people themselves (the local), negotiate over the balance of power in tourism. They see these "global-national-local interactions" as in constant flux "as players in the industry assert dominance and resist power" (Su and Teo 2009: 165). This suggestion has value in that it emphasizes the local as well as the national in heritage tourism.

Several studies are more positive with regard to the impact of tourism on culture, especially in terms of ethnic identity. In her discussion of the Tibetan communities in Shangrila, northwestern Yunnan, Åshild Kolås acknowledges the role tourism can play in Tibetan ethnic identity. She writes (2008: 50), "by (re)constructing ethnic difference, ethnic tourism has created ... a new space to negotiate ethnic identity." Moreover, this construction of difference may not be merely a question of local Tibetans following orders from the Han majority. She writes: "Tourism is not just a business where tourists use (or abuse) the commodified Tibetan, but also, and perhaps more importantly, a stage where locals can act out their own visions of Tibetan identity" (Kolås 2008: 120).

\footnotetext{
${ }^{7}$ I omit Nyíri 2006 from discussion here, because his concern is mainly Chinese tourists outside China itself.
} 
Even more forceful are the views of Bai Zhihong, who believes that tourism can actually strengthen ethnic cultural identity. Talking about the Bai 白, an ethnic group in Yunnan Province, she claims that tourism gives both intellectuals and ordinary people the chance to "capitalize on their traditional heritage" and use it in ways that suit their own perceptions of Bai culture (Bai 2007: 246). Hers is a striking statement because observers have generally assumed Bai culture to have become quite sinicized. This means that, in sharp contrast to the case with Tibetan culture, the fate of Bai culture has tended to be seen as not particularly controversial.

The authors of two Chinese Master's theses contribute to the range of positive views concerning the linkages between tourism and the traditional performing arts. One is Bi Jian 畢劍 of the Southern Jiangxi Normal College, who undertook a study of “xiqu tourism” (xiqu lüyou 戯曲旅游). Bi's argument was that tourism, culture, and commerce could each help the other two and there was nothing contradictory in the simultaneous advance of all three. Bi wrote: "Tourism is an economic product with clear cultural characteristics, and is at the same time a cultural product with obvious economic features. Following the rapid development of world tourism, the integration of tourism, the economy, and culture has become tighter and tighter” 旅游業是有着鲜明文化特徵的經濟産業，同時也是 有着鲜明經濟特徵的文化産業, 并且隨着全世界旅游業的快速發展, 旅 游、經濟與文化的結合越來越緊密 (Bi 2007: 1).

The other author is Li Youchang 李幼常, who was at Sichuan Normal University. Li researched domestic tourism performing arts. Broader than $\mathrm{Bi}$ 's thesis in that it does not focus exclusively on various forms of $x i q u$, but also narrower because it discusses only domestic tourism, Li's thesis was similar to Bi's in its highly positive conclusions. Li advanced the argument that, with government help, tourism and the performing arts had acted in a spiral-like and mutually supportive way since the mid-1980s. Tourism had promoted demand for more and better cultural experiences among the Chinese people, and was also a major factor satisfying a thirst it had created in the first place ( $\mathrm{Li}$ 2007: especially 62-63).

Finally we may note the concept of "tourist Jingju" (lüyou Jingju 旅游 京劇), ${ }^{8}$ bringing us to territory more specific to one genre among the Chinese traditional performing arts than any of the approaches mentioned above. The concept of "tourist Jingju" developed in the 1990s as a way of reviving what many saw as a magnificent but dying art form, which had

\footnotetext{
${ }^{8}$ See also Xu 1999: 519.
} 
lost its appeal to Chinese, especially young Chinese. Apart from a dwindling audience, problems Jingju faced included a declining standard of performance, a shrinking repertoire, and a dire financial situation. Zhao Hongtao 趙洪濤, general manager of an important theater in Beijing (see below) and a major figure in developing the idea of "tourist Jingju," advanced two reasons for promoting it: "one is to seize the largest audience possible at the time, the other is to spread Jingju and approach more closely the goal of making the art of indigenous Chinese theater flourish”一個是為了抓住當時最大的觀眾群，一個是為了京劇的傳播， 逐步向弘揚民族戲曲藝術中心的目標靠近 (quoted Xue 2003: 40). ${ }^{9}$

For the purposes of the present paper, all of these above-mentioned ideas are relevant. I share Greenwood's and Oakes's view that tourism alters culture, but I argue that living cultures are constantly changing anyway and that such a process need not be damaging, let alone equivalent to destruction. Far from making culture into a mere commodity, tourism can actually invigorate ethnic identities and cultures that are under threat, by giving them a commercial incentive for survival and by providing funds to train relevant professionals.

\section{Methodology, Mode of Analysis}

In this study I analyse performances that I have attended since 2006. I have lived in Beijing much of the time over those years and also travelled extensively in China, especially in the "ethnic areas" (minzu diqu 民族地 區). I have made a point of attending performances of various kinds, especially those that can be classified as xiqu or belong to minority ethnic traditions. I have relied on diaries and reviews I wrote at the time of the performances and, in one case, on memory of a performance I had just attended. I have also tried to find additional background documentation such as brochures and websites. I would also like to acknowledge insights and information from friends and colleagues. In essence, this paper is an interpretation of personal experience. Although limited by that fact, it may still have value to readers of this journal.

\footnotetext{
${ }^{9}$ Ten years ago, David Rolston wrote about "tourist Jingju" in an unpublished paper, "Matinees and Tourist Peking Opera: Two Windows on the Current Health of Jingju (Peking Opera) in Beijing." Rolston's conception of "tourist Jingju" is broader than Zhao Hongtao's, which focuses specifically on evening-length performances of shows telling the same story but performed in ways supposedly more accessible to foreigners (see below).
} 
The growth of the worldwide web has been of the greatest importance for this research. Since the late twentieth century, enterprises in more or less all countries have increasingly advertised through the Internet. They may continue to use traditional methods like posting outside the theater what is being performed that evening or in the next few days, or running ads in the newspapers, but the Internet is now by far the most important means of advertising. Indeed, special websites inform tourists, and others, about upcoming programmes. Those about to visit China, and who may have a general interest in theater, are certain to consult the web to see what is available. While websites of course do not target only people we might regard as tourists, the fact that English is prominent as a language of communication on the Internet suggests that enterprises frequently regard foreigners as among their main customers, and tourists as one of their principal clienteles. While it might sometimes be hard to distinguish between tourists and non-tourists in an audience without conducting surveys, it is fairly easy to distinguish between performances aimed specifically at tourists and those that are not.

\section{Specific Chinese Musical Performing Arts}

Shows put on especially for tourists, notably foreign ones, have become big business in China. Tours of China that emphasize heritage and traditional culture are very common, and almost always include one or more performances showcasing some aspect of Chinese culture. They often carry some kind of local flavour. As an example, I can cite an evening's performance I saw in Dunhuang in October 2010, a play with acrobatics called Dunhuang shennü 敦煌神女 (Dunhuang Goddess), which takes its story from one of the wonderful Mogao 莫高 Caves just outside the city and features the apsaras, or flying angelic entertainers of the Buddha, that are common in the Caves. Although most of the audience seemed to be foreign tourists, the show took place in the city's main theater, and locals also attended the performance.

Some of these performances for tourists take on a nationalist edge by glorifying some aspect of Chinese history and/or culture. One example is a performance I saw in May 2007 in Xi'an, capital of Shaanxi Province and formerly capital of Tang China under the name Chang'an 長安. The aim of the performance was to recreate Tang-dynasty music and dance, and in the process to present the Tang as a period of great prosperity and power. Apart from their guides, all the many spectators were apparently foreigners: Caucasian, Overseas Chinese, Japanese, and Koreans. Stagecraft, costuming, and music tended to be extravagant, with colorful 
MACKERRAS, Tourism and Musical Performing Arts

scenery projected at the back in most scenes. The producers seemed to be trying to present the grandeur of Tang life and architecture and to reconstruct the style and content of Tang art. However, overall the performance was less concerned with historical authenticity than with appealing to a modern foreign audience and showcasing what China had once been able to produce in the cultural realm. ${ }^{10}$

\section{Kunqu}

In 2001, the United Nations Educational, Scientific and Cultural Organization (UNESCO) added Kunqu to its list of "Masterpieces of the Oral and Intangible Heritage of Humanity." UNESCO's choice inevitably created a favourable impact on Kunqu as an attraction for heritage tourists and may have indirectly helped other xiqu forms as well. There had already been some interest in reviving Kunqu, and UNESCO's move gave impetus to this enthusiasm.

Since 2001, the Chinese government has taken several initiatives to promote the revival of Kunqu, possibly the most important being the 2004 decision to allocate ten million yuan per year to such ventures as staging new plays and training more professional actors (Wang 2005). For hundreds of years the performance practice of Kunqu has been to present programs of extracted scenes (zhezi xi 折子戲) rather than complete plays, which were generally written in the southern form of chuanqi 傳奇 and could be quite long. In the last couple of decades there have been several attempts to mount productions of complete chuanqi plays or greatly condensed versions that still try to represent at least the overall outline of the full story of the original. ${ }^{11}$ One play that received the latter form of treatment in the last decade was Kong Shangren's 孔尚任 Taohua shan 桃 花扇 (Peach Blossom Fan), which was originally completed in 1699 and contains 40 regular scenes plus two prologues, an interlude, and an epilogue. The producer of the new version was the Jiangsu Provincial Performing Arts Group (Jiangsu sheng yanyi jituan 江蘇省演藝集團) and it was performed by the Jiangsu Provincial Kunju Company (Jiangsu sheng Kunju yuan 江蘇省崑劇院). I saw it over the course of two

\footnotetext{
${ }^{10} \mathrm{Li} 2007$ looks at many examples of cultural shows of various genres performed for tourists.

${ }^{11}$ To celebrate the $400^{\text {th }}$ anniversary of the writing of Mudan ting (Peony Pavilion), whose preface is dated to 1598, three new productions of the play debuted in 1998-1999, in Vienna, New York and Shanghai. For reviews of these productions see Jain, ed. 2002.
} 
CHINOPERL Papers No. 30

evenings at Beijing University in October 2006, each session lasting two hours without interval. ${ }^{12}$

Perhaps the most famous chuanqi play, Tang Xianzu's 湯顯祖 Mudan ting 牡丹亭 (Peony Pavilion), gained yet another revival in 2007 through a production performed twice weekly in Beijing's old Imperial Granary. ${ }^{13}$ Lasting two hours without interval, the play was much shortened, but retained the essence of the love interest, including the dream meeting with her lover, the death, and revival of the female protagonist of the play, Du Liniang 杜麗娘. It was sensitively performed by very young actors, especially $\mathrm{Hu}$ Zhexing's 胡哲行 Du Liniang.

Comparing these two productions from the point of view of target audience, it seems to me that the Jiangsu Peach Blossom Fan was aimed mainly at university students and faculty, while the Imperial Granary Mudan ting was aimed at foreign or domestic tourists. The performance of the Jiangsu Peach Blossom Fan that I saw was part of the Beijing Music Festival, which has become an annual event aimed at promoting Beijing as an international cultural centre. It took place at Beijing University's Centennial Memorial Hall, which is a substantial theater, though hardly enormous. The choice of venue implied that the show was intended to boost the enthusiasm of the University's faculty and students for traditional Chinese culture and a speech made at the end of the Taohua shan performance by one of the actors' teachers confirmed this suggestion. This kind of campus performance of Kunqu is reminiscent of the very successful campaign undertaken by Bai Xianyong 白先勇 (a.k.a., Kenneth Pai) to make sure that his nine-hour "Young Lovers" version of Mudan ting was seen by university students in China.

While the new version of Peach Blossom Fan is only performed on special occasions and is not in regular production, ${ }^{14}$ the Imperial Granary Mudan ting has been performed weekly since it premiered in 2007. The theater at the Imperial Granary is quite small, but on all three occasions I

\footnotetext{
12 To distinguish their version from the original, 1699 was added to the title. The DVD version (recorded in March of 2005 and published by Jiangsu wenhua yinxiang 江 蘇文化音像) runs for a little over three hours and contains the script, which is divided into six scenes.

${ }^{13}$ See Mackerras 2010.

${ }^{14}$ Even the far more successful "Young Lovers" version of Mudan ting took several years to reach its 100 th performance, which was marked by the publication of a new DVD version of the production.
} 
MACKERRAS, Tourism and Musical Performing Arts

have attended, either all or nearly all the spectators seemed to be from Western countries. The text, both dialogue and arias, was projected both in Chinese and English, with a detailed programme in both languages. The cost of the tickets is high. It is clear that this production is aimed mainly at foreign tourists, especially the richer ones, in other words, not backpackers. Although one suspects that the producers are making good money, the production can also be seen as part of an attempt to use tourism to revive and strengthen a major branch of the traditional Chinese performing arts.

If we accept the suggestion cited earlier that contemporary authenticity "pays homage to the 'original' concept," then the Imperial Granary Mudan ting actually came off as more "authentic" than the Jiangsu Peach Blossom Fan. The staging of Mudan ting was simple and intimate, with a very small stage, quite similar to practice in the Ming dynasty. On the other hand, Peach Blossom Fan's staging was quite modern, with scenes from seventeenth-century Nanjing projected onto a scrim hung at the back of a large stage. The orchestra of Mudan ting was small, containing only instruments in standard use in Tang Xianzu's time, especially the sideblown dizi 笛子. By contrast, the Peach Blossom Fan orchestra was large, with some non-traditional instruments such as lower-pitched string instruments, and even had a conductor standing in front of it, Western style. Of course, it is arguable that elements of the Peach Blossom Fan production attempted to reflect traditional practice but in a modern way. For instance, the orchestra was placed at the back of the stage, dimly visible through the scrim with the projection on it, and that placement was perhaps meant to recall the days when the orchestra took its place at the back of the stage, as can be seen in $19^{\text {th }}$ century popular prints.

My conclusion is that credit for the Kunqu revival belongs much less to tourism than to the UNESCO decision to add the genre to its list of "Masterpieces of the Oral and Intangible Heritage of Humanity," and associated Chinese advocates and enthusiasts who both supported the nomination and were energized when it succeeded. While tourism is thus not the primary driver of the revival, it has certainly helped in a range of ways. Ironically, the tourist hunger for authenticity appears to have been a factor contributing to the new Kunqu.

\section{Jingju}

One strategy that uses tourism to revive the fortunes of traditional Chinese theater, and which directly relates to the question of authenticity, is to mount productions that echo or include elements of past performance practices. The earliest prominent example of this, with reference to Jingju, 
is Liyuan juchang 梨園劇場 (Liyuan [Pear Garden] Theater) a theater located within Qianmen fandian 前門飯店 (Qianmen [Front Gate] Hotel), a major Beijing tourist hotel. ${ }^{15}$ It opened in 1990 with an investment of 800,000 RMB from the Beijing Tourist Bureau (Cui 1996: 74-75). The items performed in the theater all come from the traditional repertoire, even if they have been carefully picked and "edited" to appeal to western audiences. Although Liyuan juchang copies the theaters of the past in some respects (for instance, spectators seated in the half of the first floor closest to the stage sit at tables and are served tea and snacks), it is otherwise a modern theater with a wide proscenium stage.

A related development is the restoration of old theaters that had fallen into disuse. These refurbished theaters have to a large extent become tourist attractions and sites where tourists are told they can see "authentic" old-style performances of Jingju items. Two worth mentioning are Zhengyi ci xilou 正乙祠戯樓 (Zhengyi Temple Theater) and the theater in Huguang huiguan 湖廣會館 (Huguang Native Place Association). The former opened for public performances in 1995, the latter in 1997. Zhengyi ci xilou has encountered more difficulties, and also been more open to innovation than Huguang huiguan. However, in both cases the management has tried hard to recapture the past in ways they regard as authentic.

Huguang huiguan has been far more successful commercially. One factor in its success is that it is located on a busy corner and has its own parking lot, while Zhengyi ci xilou, a much older theater, is located up a quite narrow road where there are no parking facilities. While Huguang huiguan has been in continuous operation since it opened to the public, Zhengyi ci xilou has been closed for extensive periods during which the project was being retooled and rethought. A website of the ten best "nightlife" theater sites in Beijing has a short statement on the Huguang huiguan theater, part of which reads: "Of the dozens of venues offering this historic musical theatre [Jingju], this is the most atmospheric" (10Best n.d.), but does not mention Zhengyi ci xilou. A piece on the Huguang huiguan theater in China Daily entitled "China's Globe Theater" (China Daily reporter 2008) suggests that both the efforts of the Ministry of Education to introduce Jingju into the nation's school curriculum and the activities at the Huguang huiguan theater were evidence of a general revival of interest in this old art. The article also acknowledges that

\footnotetext{
${ }^{15}$ The official English language website for the hotel (see Qianmen Jianguo Hotel n.d.) refers to the hotel as a "Beijing Opera Theme Hotel."
} 
MACKERRAS, Tourism and Musical Performing Arts

Huguang huiguan "caters mainly for tourists." This piece also quoted the general manager to the effect that Jingju was flourishing and could survive for 1,000 years. Another website (Frommer's 2011) claims that Zhengyi ci xilou "is similar to the [theatre at] Huguang Guild Hall [Huguang huiguan], with the same high ceilings and gallery seating, but it has a decidedly more local feel. The staff themselves are connoisseurs, more interested in opera than collecting tourist dollars." However, it also concedes that Zhengyi ci xilou does not give performances as frequently and is suffering financially.

Having visited both places, I can offer several points of comparison and contrast that stand out to me and may bear on some of the issues raised in this article. I first saw a performance at Zhengyi ci xilou soon after its 1995 opening and again in October 2011. During 2010, I attended three evening performances at Huguang huiguan.

Both theaters were originally the private theaters of native place associations ${ }^{16}$ and designed for fairly small audiences, though the Zhengyi ci xilou stage is considerably larger than Huguang huiguan's. The audiences at all performances I attended in 2010 at Huguang huiguan consisted entirely of foreigners. The performances there, which are made up mostly of extracts from zhezi $x i,{ }^{17}$ cater to tourists, especially those from overseas and those with money. ${ }^{18}$ The self-published booklet available to visitors to Zhengyi ci xilou mentions receiving foreign dignitaries and many foreign experts and tourists, adding: "Tens of thousands of tourists from Hong Kong, Macau, Tai Wan [sic.] pour into here to appreciate the beauty of this theater" (Zhengyi ci n.d.: 9). The manager of Zhengyi ci xilou told me on October 21, 2011 that he has four groups in mind as clientele: foreign visitors, specialists (zhuanjia 專家) on

\footnotetext{
${ }^{16}$ In the seventeenth century, Zhejiang bankers and merchants created a native place association on the site of a Buddhist temple named Zhengyi ci, which might explain why the theater is referred to as a temple. It is unclear as to whether the original temple had a theater, but in any case the existing theater is much more on the model of a native place association theater than a temple theater.

${ }^{17}$ Zhezi $x i$ are already extracted scenes from a longer play, so some of the items performed are actually "extracts from extracts."

${ }^{18}$ I understand that on the weekends the matinee performances have traditionally been more standard fare (longer, more reflective of the repertoire as a whole) and cater to a more knowing crowd of local Beijingers and domestic tourists. Also, every weekend a well-known amateur Jingju club holds public meetings for which tickets are sold that feature the singing of undramatized arias (so-called "pure singing" [qingchang 清唱]) by both amateurs and professionals with full orchestral accompaniment.
} 
CHINOPERL Papers No. 30

Jingju and Chinese theatre, tourists, and businessmen. The audience at the performance I attended on that day was mostly Chinese but many of them seemed to be from Hong Kong, Macau, and Taiwan. There were also some non-Chinese.

Since its opening to the public in 1995, Zhengyi ci xilou has encountered some problems. First, it closed because of a lawsuit and did not reopen until 1999. Then, it closed again for refurbishment and did not reopen until May 2006 (Zhengyi ci n.d.: 10). ${ }^{19}$ All my calls to the theater in 2010 turned up no performances for that evening.

However, as advertised in the section on theater on the website of China Art International Travel Service (Beijing-Travels.com n.d., "Beijing Zhengyi Ci Theater"), there have been showings of excerpts from Mei Lanfang 梅蘭芳 classics at the theater every Friday and Saturday night since December 5, 2010. Mei (1894-1961) is the famous male actor of female roles (nandan 男旦), and probably the best-known performer, domestically or internationally, that China has ever produced. ${ }^{20} \mathrm{~A}$ booklet to accompany and introduce the performances of these excerpts, with sections both in Chinese and English (but with the latter in some places only summarizing rather than translating the content of the former) is available at the theater. One of the English sections says: "If watching Beijing Opera is a must choice for tourists in Beijing, then 'Mei Lanfang's Classics' is the best choice" (Zhengyi ci xilou 2010: 23). I was able to attend a performance on October 21, 2011.

The website shows the locations of the almost 200 seats one can chose from on the first floor (the seats on the second floor are not included), and shows that the tables have been removed so that more seats can be fit in (Beijing-Travels.com n.d., "Beijing Zhengyi $\mathrm{Ci}$ Theater"). The performance I attended was not particularly crowded: there were some 100 people, with the occupants of the cheapest seats at the back being allowed to move forward once the performance had started. Perhaps to handle the parking problem already mentioned, the website says that it can arrange for a car and driver to pick you up. Information on how to take a taxi to the theater is also given (Beijing-Travels.com n.d., "Beijing Zhengyi Ci

\footnotetext{
${ }^{19}$ The booklet (it is actually over forty pages, hardbound, in large format) is undated, but the language here and the lack of mention of later dates or developments makes it very likely that it was originally produced for this 2006 reopening. A very small notice on the second to last page of the book claims that the book is only for publicity purposes and not for sale.

${ }^{20}$ For a collection of texts about Mei, see Tian, ed. 2010.
} 
Theater"). A Chinese performance ticketing site, addressed primarily to a Chinese audience, contains the slogan, in English, "Six Mei Lanfang Classics in 100 Minutes, A Panorama of Peking Opera" (piao.com.cn n.d.). ${ }^{21}$ An interesting feature is that the theatre itself contains a room with a life-size wax figure of Mei Lanfang, with an empty chair provided so that visitors can be photographed sitting with the master.

Both Huguang huiguan and Zhengyi ci xilou have interesting histories. The Huguang huiguan complex, which also contains a theater museum, has been described in the tourist promotional literature as the best preserved of the hundreds of Ming and Qing native place associations or guild halls in Beijing ("Beijing Theater Museum" n.d.). The program issued for the "Mei Lanfang Classics" (Zhengyi ci xilou 2010: 24-25) claims that the Zhengyi ci cilou theater dates from 1712 and is China's oldest all-wooden indoor theater. It has seen performances by many famous actors, including Cheng Changgeng 程長庚 (1811-1880), Tan Xinpei 譚金培 (1847-1917), and Mei Lanfang (Zhengyi ci n.d.: 7), as well as several generations of the Mei family (Zhengyi ci xilou 2010: 6).

The management of both theaters has gone out of its way to portray both the theaters and performances held in them as traditional. The stages themselves are of the traditional bare thrust type with pillars at both front corners, with a traditional non-scenic changeable backdrop (shoujiu 守舊) and entrances on either side of it covered by hangings that are manually pulled aside when actors enter or exit the stage. Since there is no curtain to pull, the traditional system of having prop men come on stage to move props (jianchang 檢場) is used.

In both theatres, items performed tend strongly to the traditional. At Huguang huiguan all items are chosen to represent different aspects of classical performance and music. The Mei Lanfang classics I saw in October 2011 at Zhengyi ci xilou all followed his style closely in terms of singing, costumes, and movement. ${ }^{22}$ The artistic supervisor (yishu zongjian 藝術總監) was Mei Lanfang’s son Mei Baojiu 梅㭉㺵 (1934- ),

\footnotetext{
${ }^{21}$ The name of the program, which is the same every performance, is "Mei Lanfang hua" 梅蘭芳華 (The Cream of Mei Lanfang). While this site does not include a seating plan, it does give prices for box seating (baoxiang 包廂). Costs range from a low of 280 yuan to 18,000 for a VIP box for 12 people.

${ }^{22}$ The troupe that provides the actors is the Mei Lanfang Jingju Troupe (Mei Lanfang Jingju tuan 梅蘭芳京劇團) of the Beijing Jingju Company (Beijing Jingju yuan 北京京 劇院).
} 
himself well known as a nandan actor and major follower of his father's style.

On the other hand, the director (daoyan 導演) of the evening of Mei Lanfang classics was Li Liuyi 李六乙, and the show began very nontraditionally with a projected photographic history of Mei Lanfang's life that followed a style I have seen elsewhere in Li's work. An interesting artistic innovation in the theater is the addition of a walkway built from the stage based on the hanamichi 花道 familiar to audiences of the Japanese kabuki. It was introduced, according to an informant at the theatre itself, because it enabled audiences to see the performers better. In the items I saw in October 2011, it was not actually used very much, but to good effect when it was. For example, at the beginning of the evening, the actors actually entered the stage along the walkway, and several dance sections in the excerpt from Bawang bieji 霸王別姬 (The Hegemon Says Farewell to His Concubine) were performed on it.

Authenticity appears to remain important, though more for Huguang huiguan than for Zhengyi ci xilou. This can be seen from the efforts made to recreate and revive glories of past Jingju art. But to reopen these theaters has proved expensive, and more likely to appeal to visitors/tourists than to locals. Both do their best to attract a tourist clientele, and screen the texts of the Jingju both in Chinese and English.

There are other important Jingju centres in Beijing. One of the biggest is Chang'an Grand Theater (Chang'an da xiyuan 長安大戯院) near Jianguo Gate on the eastern portion of Chang'an Boulevard, which replaced the 1937 theater of the same name in 1996, after the older version, located at the other end of the boulevard at Xidan, was torn down. The older version did have a thrust stage that could sit the audience on three sides, but the seats themselves were arranged in western-style rows. In the new version of the theater, there is a big modern proscenium stage, but traditional tables and chairs in the front half of the first floor and auditorium seating in the back half and balcony. Outside the theater are shops with recordings of various kinds, including Jingju, and other objects for sale. The items performed there are sometimes accompanied by English subtitles, but not always, unlike Liyuan juchang, where English subtitles are always provided for the evening performances.

The person mainly responsible for the new version of Chang'an Grand Theater is Zhao Hongtao, whom we have already met in connection with the concept of "tourist Jingju." He has tried to bring about a revival in China's traditional performing arts in Beijing through appeals to tourists, 
both foreign and Chinese, as well as through education. This is one reporter's understanding of what Zhao wanted to do:

The tourist performances of other theaters are all zhezi $x i$, but those watching them are mostly foreigners who know very little about traditional Chinese culture and don't understand Chinese. Zhezi xi lack beginnings or endings, and they are performed in the traditional way with just a table and two chairs for props and with just traditional singing, recitation, acting, and martial acrobatics; foreigners can't make any sense out of them. Chang'an could not follow that old way of doing things, it wanted to put together "tourist Jingju" that fit the taste of tourists, and that told a story from beginning to end, taking a complete play and condensing down to within 90 minutes, and borrowing to the utmost degree possible forms from other Chinese artistic traditions, in order to make foreigners be able to understand the play on first viewing. 別的劇場的旅游演出都是折子戲, 看戲的多數是對中國傳統文化 知之甚少, 語言不通的老外, 折子戲都是沒頭沒尾的故事, 形式上 依然是傳統的一桌兩椅, 唱念做打, 外國人既不明白更看不懂. 長 安不能走老路, 要搞適應旅游者口味的“旅游京劇,”講有頭有尾 的故事, 把整齣戲濃縮在 90 分鐘裡,要儘可能地借鑒我國其他民 間藝術形式,讓外國人一看就懂. (Xue 2003: 40)

Zhao's "tourist Jingju" plays still make use of traditional Jingju stories and costumes, and much of its style and music, but the stagecraft and music are often adapted to suit supposed Western tastes. For example, Western musical instruments are added to the orchestra and the falsetto singing characteristic of some Jingju roles is reduced or eliminated. What is clear is that Zhao definitely had foreign tourists in mind as targets to help improve the fortunes (literal and figurative) of Jingju and his theater but the later projects and policies he implemented at the same theater show that they are not the only people he cares about. ${ }^{23}$

\footnotetext{
${ }^{23}$ Although the four examples of specific "tourist Jingju" plays mentioned in Xue 2003 all had been performed more than 100 times at the time that that article was written, they do not make up even a small proportion of the performances in a typical month at the theater nowadays. In fact, by the time Zhao was interviewed in 2006 on the tenth anniversary of the opening of the theater, he had distanced himself from the term "tourist Jingju" and instead was touting the fact that $70 \%$ of the Jingju performances at the theater were wenxi 文戲 (“civil” plays) that featured singing, which he identified as the
} 
Another significant venue is Mei Lanfang Grand Theater (Mei Lanfang da juyuan 梅蘭芳大劇院), which opened to the public late in November 2007 (Beijing-Travels.com n.d., "Beijing Mei Lanfang Grand Theater"). It is owned and operated by the national Jingju troupe and has excellent performances that are not translated into English. Both times I went there, the audience was quite respectable, though the theater was hardly booked out. Almost all spectators were Chinese, with only a few foreign faces. The age of the audience was generally fairly high, though there were some very small girls. There is an English-language website, and some attempt to appeal to foreign tourists has been made, but the main emphasis definitely appears to be on local Jingju-lovers. ${ }^{24}$

Finally, the National Center for the Performing Arts (Guojia da juyuan 國家大戯院) is the largest and most varied of performing arts centres in Beijing. Known as "the egg" for its shape, it is just beside Tiananmen Square, was designed by French architect Paul Andreu, and opened at the end of 2007. The complex contains a number of separate theaters featuring various kinds of performances, including Western opera, traditional Chinese theater, ballet, and Western music concerts. Although Jingju performances do not predominate in terms of the genre of items performed, they are reasonably frequent. I saw there in 2009 and 2010 the "model revolutionary drama” (geming yangban xi 革命樣板戯) Shajiabang 沙家 浜 and a newly produced item Chibi 赤壁 (Red Cliff). Neither tried to replicate traditions older than the Cultural Revolution, while the second of them, about the famous Three Kingdoms battle at that site, featured spectacular and up-to-date stage devices and newly composed music that differed from traditional Jingju music. Though the second had surtitles in Chinese and English, and there were evidently quite a few tourists in the audience, they did not appear to be the primary target. By building the National Center, the Chinese government is clearly aiming to appear modern to the world. The date of the opening suggests that one of the aims was to attract overseas visitors during the Olympic Games of August 2008. However, during the many times I have visited the National Center for concerts, operas, ballets, and other performances, I have been struck by the fact that the audiences appear to be mainly local. The National Center

most fundamental aspect of Jingju (Feng Jie 2006). This might be related to the fact that the "tourist Jingju" plays were thought by many to not even be Jingju (a problem already noted in Xue 2003: 40 and stated more forcibly in Qiao 2007: 69).

${ }^{24}$ Seating is auditorium style throughout, although there is some box seating in the balcony. 
may play a role in reviving traditional Jingju, but it will not be a crucial one.

The prominent role of tourism in the contemporary Jingju scene in Beijing is obvious. But there are certainly other factors that are important as well. It is interesting that, in refurbishing Zhengyi ci xilou, the manager said that he was trying to appeal to specialists in Chinese theatre as well as tourists. Although most of the theaters seemed interested in bringing in the tourist trade by presenting their performances as revivals of past cultural glories, not all did this. For the National Center, for instance, being modern and progressive seemed to be more important than being authentic.

\section{Minority Performing Arts}

Ethnic tourism is among the actively promoted kinds of tourism in contemporary China. In addition to issues of cultural sensitivity and survival, it raises the additional dimension of ethnicity and inter-ethnic relations. The fact that so much of the English-language literature on tourism in China deals with ethnic minorities or ethnic areas merely confirms how important this matter has become to Western scholars. ${ }^{25}$

Among China's ethnic minority performance arts, the one the tourist trade most emphasises is song-and-dance. Tours to Yunnan or Xinjiang are likely to include song-and-dance performances. Often these take place in theaters within hotels where foreign tourists stay, while in Xinjiang the audience frequently sits beneath grape-vines. The performances preserve at least some elements of old practice, but not the social context.

Kolås (2008: 93) explains that "so-called 'ethnic song and dance' features prominently in any type of cultural presentation for tourists" in Yunnan, including in the Tibetan region of Diqing Autonomous Prefecture. She cites performers at the Nationalities Village (Minzu cun 民族村), an ethnic theme park near Kunming, to the effect that "by working here we can help preserve our culture" (Kolås 2008: 96). She also visited a "theme park" near the Diqing prefectural capital Zhongxin, which was owned by a Tibetan entrepreneur. There she visited a Tibetan family house featuring Tibetan culture, including song and dance, the great majority of customers being Han. Commercially, it is successful and meets the demands of the Han visitors. However, Kolås claims that "what such performances present is not the 'authentic' Tibetan culture, but the 'themed culture' that most Chinese tourists expect”' (Kolås 2008: 98).

\footnotetext{
${ }^{25}$ See the items discussed in the section "Theory" above.
} 
Prominent among the ethnic minority song-and-dance forms is the Twelve Muqam of the Uygurs. Since the 1950s, there have been major efforts to preserve and strengthen this set of twelve items, which official discourse claims to have been collected into something like their present form by Amannisa Khan (1526-1560), wife of the Yarkant ruler. ${ }^{26} \mathrm{~A}$ major point in the contemporary revival, though certainly not the beginning, was in November 2005, when UNESCO proclaimed the Twelve Muqam among the "Masterpieces of the Oral and Intangible Heritage of Humanity." Several CDs and DVDs of the Muqam have been published. One important and "official" one came out in 2002 with twelve VCDs, sponsored by Xinjiang's cultural authorities. I was able to buy a copy in Kashgar when I visited the city in 2003. Its style is designed to follow traditional patterns, its production magnificent, and the dancing, singing, and instrumental playing are all very beautiful. Many official and professional bodies were involved in its production and publication. The creators of this "standard" version of the Twelve Muqam are almost all Uygurs, with Han participation, let alone intervention, very limited. The running time of the whole set of VCDs is about 24 hours. This makes it very difficult to perform the sequence in full for tourists, although a much shortened version along the lines of the Imperial Granary production of Mudan ting would be quite possible. The original version of the VCDs had subtitles and explanations only in Uygur. Later, a new edition of the same performances was issued with subtitles not only in Uygur, but also in Chinese, English, and Arabic, suggesting that the market has expanded beyond the Uygur community. ${ }^{27}$

In Xinjiang tourism, songs and dances in the style of the Twelve Muqam have for long received a great deal of attention. However, there is apparently still not much of an attempt to offer high-standard and largely authentic performances for tourists. In October 2010, as leader of an educational tour of Xinjiang, I was able to get the updated version on DVD of the Twelve Muqam mentioned above, but in terms of live performances there was only an evening of amateur songs and dances

\footnotetext{
${ }^{26}$ On Amannisa Khan's role, see Harris 2008: 69-72.

27 Tomur Dawamet, chief planner, Ablet Abdurexit, chief supervisor, Abliz Abdurehim, chief producer, Umar Sayim, Kurbanjan Heyit, et al., directors, Halik Haji et al., music directors, musicians from Xinjiang Arts College, Zhongguo Weiwuer shier mukamu 中國維吾爾十二木卡姆 (Chinese Uighur Twelve Muqam), sponsored by the Department of Culture of Xinjiang Uygur Autonomous Region, Xinjiang People's Broadcasting Station, Xinjiang Arts College et al., Urumqi: Xinjiang Audio Video Publishing House, DVD Video, no date given.
} 
MACKERRAS, Tourism and Musical Performing Arts

modelled on the Twelve Muqam and offered under grape-vines with a Uygur dinner. There are some websites on the Twelve Muqam appealing to Western tourists, but they do not actually promise performances of all or part of the collection. ${ }^{28}$ On the other hand, Amannisa Khan's tomb, together with those of her husband and small baby (she actually died in childbirth), are featured in any tour that includes Yarkant.

In a major book on the muqam, Rachel Harris argues that nationalists have made them into more or less fixed canons in the twentieth century. She praises the UNESCO initiative for empowering new actors and giving "new agency to contending voices concerning the preservation and practice of muqam in the region" (Harris 2008: 138). She also expresses concern about the potential negative impact of the UNESCO initiative, "with local muqam traditions becoming increasingly commercialised and exploited in Xinjiang's exploding tourism market" (Harris 2008: 139). However, tourism also has the potential to widen audiences for the muqam and bring in money that could be used for purposes like training further artists. This could strengthen the muqam as a body of Uighur national art heritage.

The oldest genre of China's ethnic minority dramas is the ache lhamo of the Tibetans, ${ }^{29}$ and its age and distinction entitle it to a mention here, even if only briefly. Probably dating from the fifteenth century, it has, since the seventeenth century, been performed at the Dalai Lama's summer palace Norbu Lingka as part of the summer Shoten Festival (Yoghurt Banquet). I have seen performances of ache lhamo at the Norbu Lingka and elsewhere in Lhasa, with the audience consisting almost entirely of Tibetans, with few Chinese or foreign tourists. Up to now, ache lhamo has not become a major tourist attraction. A Nepalese web-site (Holiday Nepal) advertises a ten-day "Tibet Shoton Festival 2011" tour in late summer, but it is actually unclear how much ache lhamo is included.

\section{Conclusion}

The effects of tourism, and especially heritage tourism, on cultural preservation are various. In several of the cases noted above, such as Kunqu and the Uygur Twelve Muqam, UNESCO recognition has helped drive revival. Tourism also has the potential to strengthen such revivals. The kind of commercialization that tends to come with tourism could easily make artists try to appeal to foreign tourists rather than maintaining

\footnotetext{
${ }^{28}$ For example, see China Tour yeschinatour.com, "Twelve Muqam."

${ }^{29}$ See the discussion in Mackerras 1992, especially pp. 3-7.
} 
authenticity. Since what many Western tourists want above all is authenticity, to say that they heard or saw the real thing, tourism and authenticity need not necessarily be at odds. And it is also possible that authenticity can coexist with innovation, as appears to me to be happening at Zhengyi ci xilou.

The domestic tourism market may be less interested in authenticity than the foreign one, if only because the idea of mass tourism is somewhat newer for Chinese citizens than for those of Western countries. According to Nyíri (2006: 80), in China "authenticity has not been a concern of the modern," and environmental movements that might wish to preserve the authentic against possible commercialization are much weaker in China than in the West. The "ethnic song-and-dance shows" that occur so commonly in tours of minority regions place far less emphasis on authenticity than a project such as the DVDs of the Twelve Muqam. The former are more a changed than an authentic tradition.

Another problem with commercialization is the possibility of collapse if the economic situation deteriorates. Although tour operators and almost all travel agencies are state-owned, and the state maintains the power of veto in all arts production, private companies and foreign investment can be involved in providing performing arts entertainment and there is no guarantee that the state will step in to save enterprises at risk.

Among tourists who can assist heritage preservation, it is the rich mainstream ones who make the biggest contribution, not the backpackers. Good productions of traditional performances do not come cheap. Such mainstream tourists usually come from outside mainland China. They may well be ethnically Chinese, but that does not mean they necessarily count as domestic tourists.

It seems to me that living cultures change by nature. A changed culture is not necessarily a destroyed culture. There is no point in trying to make a perfect replica of an ancient art. On the other hand, it is good to try to preserve and, if necessary, revive beautiful traditional art forms, including those of ethnic groups holding only minority status within powerful modern states.

Tourism is not necessarily a driver of such attempts at cultural preservation, nor are all attempts to revive heritage items aimed specifically at tourists. However, tourism has the potential, if handled carefully, to assist greatly in the cause of cultural preservation. It certainly brings in money, giving traditional culture a commercial impetus for revival, and can provide funding for the training of professionals. It also has the potential to strengthen or revive ethnic identities and promote 
MACKERRAS, Tourism and Musical Performing Arts

Chinese national cultures to the outside world. Tourism ought not to be dismissed outright as necessarily harmful and should certainly be taken seriously. 
CHINOPERL Papers No. 30

\section{REFERENCES}

10Best. n.d.

"Huguang Huiguan." 10Best Trusted Advice for Travelers. http://www.10best.com/destinations/china/beijing/all/nightlife/huguang -huiguan/, accessed February 13, 2011.

Bai Zhihong. 2007

"Ethnic Identities under the Tourist Gaze." Asian Ethnicity 8.3: 24559.

Beijing-Travels.com. n.d.

"Beijing Mei Lanfang Grand Theater." http://www.beijing-travels.com/ beijing guide/theater/mei_lanfang_grand.html, accessed February 13, 2011.

Beijing-Travels.com. n.d.

"Beijing Zhengyi Ci Theater." http://www.beijing-travels.com/ beijing guide/theater/zhengyici.html, accessed February 13, 2011.

"Beijing Theater Museum.” n.d.

http://www.chinamuseums.com/beijing theater.htm, accessed February $13,2011$.

Bi Jian 畢劍. 2007

“Xiqu lüyou de kaifa yanjiu” 戯曲旅游的開發研究 (A Study on the Development of Xiqu Tourism). Gannan Normal University (Gannan shifan xueyuan 赣南師范學院) Master's thesis, Ganzhou.

Chhabra, Deepak, Robert Healy, and Erin Sills. 2003

"Staged Authenticity and Heritage Tourism." Annals of Tourism Research 3:702-19.

China Daily Reporter (unnamed). 2008

"China's Globe Theater." China Daily, September 17, 2008. http://www.chinadaily.com.cn/video/2008-09/17/content_7713308.

htm, accessed February 13, 2001.

China Tour yeschinatour.com. n.d.

"Twelve Muqam." http://yeschinatour.com/china-guides/chineseculture/twelve-muqam/, accessed February 15, 2011.

Cingcade, Mary L. 1998

"Tourism and the Many Tibets: The Manufacture of Tibetan

'Tradition.'” China Information 13.1 (Summer): 1-24. 
MACKERRAS, Tourism and Musical Performing Arts

Cui Changwu 崔長武, ed. 1996

Jingju xianzhuang yanjiu 京劇現狀研究 (Research on the Present Condition of Jingju). Beijing: Zhongguo xiju.

Feng Jie 封杰. 2006

"Jiang shichang linian rongru Jingju benti-Fang Beijing Chang'an da xiyuan zong jingli Zhao Hongtao xiansheng” 將市場理念融入京劇本 体一訪北京長安大戲院總經理趙洪濤先生 (Integrating the Concept of the Market into the Ontology of Jingju-An Interview with Mr. Zhao Hongtao, General Mangager of the Chang'an Great Theater). Zhongguo Jingju 中國京劇 (China Jingju) 12: 4-6.

Frommer's. 2011

"Zhengyi Ci Xilou (Zhengyi Ci Theater)." http:// www. nileguide. com/destination/beijing/bars-and-clubs/zhengyi-ci-xilou-zhengyi-citheater/330501, accessed February 13, 2011.

Greenwood, Davydd J. 1989

"Culture by the Pound: An Anthropological Perspective." In Valene L. Smith ed. Hosts and Guests: The Anthropology of Tourism. Second Edition. Philadelphia: University of Pennsylvania Press, 171-86.

Harris, Rachel. 2008

The Making of a Musical Canon in Chinese Central Asia, The Uyghur Twelve Muqam. Aldershot, Hampshire and Burlington VT: Ashgate.

Holiday Nepal. n. d.

"Tibet Shoton Festival 2011." http://www.holidaynepal.com/tibet/ shoton-festival-tibet-2010.html, accessed February 16, 2011.

Jain, Susan Pertel, ed. 2002

"Contemplating Peonies: A Symposium on Three Productions of Tang Xianzu's Peony Pavilion.” Asian Theatre Journal 19.1: 121-60.

Kibby, Marjorie. 2000

"Tourists on the Mother Road and the Information Superhighway." In M. Robinson, P. Long, K. Evans, R. Sharpley, and J. Swarbrooke, eds. Reflections on International Tourism: Expressions of Culture, Identity, and Meaning in Tourism. Newcastle: University of Northumbria, 13949.

Kolås, Åshild. 2008

Tourism and Tibetan Culture in Transition, A Place Called Shangrila. London and New York: Routledge. 
CHINOPERL Papers No. 30

Lew, Alan A., Lawrence Yu, John Ap, and Zhang Guangrui, eds. 2003

Tourism in China. New York, London, Oxford: The Haworth Hospitality Press.

Li Youchang 李幼常. 2007

“Guonei lüyou yanyi yanjiu”国内旅游演艺研究 (“A Study of the Performing Arts in Domestic Tourism”). Sichuan Normal University (Sichuan shifan daxue 四川師范大學) Master's thesis, Chengdu.

Mackerras, Colin. 1992

"Integration and the Dramas of China's Minorities," Asian Theatre Journal 9.1: 1-37. 2010

"Performance Review: The Imperial Granary Production of Mudan Ting (The Peony Pavilion)." CHINOPERL Papers 29: 209-216.

Nyíri, Pál. 2006

Scenic Spots, Chinese Tourism, the State, and Cultural Authority. Seattle and London: University of Washington Press.

Oakes, Timothy. 1998

Tourism and Modernity in China. London and New York: Routledge.

Piao.com.cn. n.d.

“Zhengyi ci xilou ban Jingju Mei Lanfang hua” 正乙祠戲樓版京劇梅 蘭芳華 (The Zhengyi ci cilou Jingju Production, "Mei Lanfang Classics"). http://www.piao.com.cn/ticket_20522.html, accessed May 6, 2011.

Qianmen Jianguo Hotel. n.d.

"Beijing Opera Theme Hotel." http://www.qianmenhotel.com/en/ index.html, accessed June 20, 2011.

Qiao Yu 喬玉. 2007

“Jingju yu shichang” 京劇與市場 (Jingju and the Market). Da wutai 大舞臺 (The Great Stage) 2: 69.

Rolston, David. Unpublished

"Matinees and Tourist Peking Opera: Two Windows on the Current Health of Jingju (Peking Opera) in Beijing." 
MACKERRAS, Tourism and Musical Performing Arts

Ryan, Chris and Gu Huimin. 2009

"Introduction: The Growth and Context of Tourism in China." In Chris Ryan and Gui Huimin, eds. Tourism in China, Destination, Cultures and Communities. London and New York: Routledge, 1-8.

, and Fang Meng. 2009

"Destination Planning in China." In Chris Ryan and Gui Huimin, eds. Tourism in China, Destination, Cultures and Communities. London and New York: Routledge, 11-37.

Schippers, Huib. 2010

Facing the Music, Shaping Music Education from a Global Perspective. Oxford and New York: Oxford University Press.

Su, Xiaobo and Peggy Teo. 2009

The Politics of Heritage Tourism in China, A View from Lijiang. London and New York: Routledge.

Tian, Min, ed. and introduction. 2010

China's Greatest Operatic Male Actor of Female Roles, Documenting the Life and Art of Mei Lanfang, 1894-1961. Lewiston, ME: Edwin Mellen Press.

Urry, John. 2002

The Tourist Gaze. London: Sage.

Visit Our China. n. d.

"China Opera," http://www.visitourchina.com/guide/china_opera.htm, accessed February 14, 2011.

Wang Li. 2005

"The Rebirth of Kunqu Opera," The New Courier (Journal of the United Nations Educational, Scientific and Cultural Organization). http://portal.unesco.org/en/ev.php-URL_ID=30513\&URL_DO=DO

TOPIC\&URL_SECTION=201.html, accessed February 14, 2011.

Weaver, David, and Martin Opperman. 2000

Tourism Management. Milton, Qld.: Jacaranda Wiley.

Wen, Julie Jie, and Clement A. Tisdell. 2001

Tourism and China's Development, Policies, Regional Economic Growth and Ecotourism. Singapore: World Scientific.

Xu Chengbei 徐城北. 1999

Jingju yu Zhongguo wenhua 京劇與中國文化 (Jingju and Chinese Culture). Beijing: Renmin chubanshe. 
CHINOPERL Papers No. 30

$\mathrm{Xu}$, Gang. 1999

Tourism and Local Economic Development in China, Case Studies of Guilin, Suzhou and Beidaihe. Richmond, Surrey: Curzon.

Xue Xiaojin 薛曉金. 2003

“Zhao Hongtao chuangxin zai Chang'an”趙洪濤創新在長安 (Zhao Hongtao Creates Something New at the Chang'an). Beijing zhibu shenghuo 北京支部生活 (Party Section Life in Beijing) 1: 40-41.

Zhengyi ci xilou 正乙祠戯樓. n.d.

Fenghua juedai Zhengyi ci, baohu chuantong wenhua, chongxian guocui fengcai 風華绝代正乙祠, 保護傳統文化. 重現國粹風采/The most brilliant traditional Chinese theatre, Protect the traditional culture and revitalize the charms of the quintessence of the Chinese nation. Bilingual booklet self-published by Zhengyi ci xilou.

Zhengyi ci xilou 正乙祠戯樓. 2010

Mei Lanfang hua 梅蘭芳華/Mei Lanfang Classics. Bilingual booklet published by PoloArts and Zhengyi ci xilou.

Zhou, Yong-Guang, and Emily Ma. 2009

"Maintaining the Authenticity of Rural Tourism Experiences through Community Participation, The Case of Two Baiyang Lake Island Villages." In Chris Ryan and Gu Huimin, eds. Tourism in China, Destination, Cultures and Communities. London and New York: Routledge, 293-307. 